TITLE:

\title{
One-step preparation of amino- PEG modified poly(methyl methacrylate) microchips for electrophoretic separation of biomolecules
}

\section{$\operatorname{AUTHOR}(S):$}

Kitagawa, Fumihiko; Kubota, Kei; Sueyoshi, Kenji; Otsuka, Koji

\section{CITATION:}

Kitagawa, Fumihiko ...[et al]. One-step preparation of amino-PEG modified poly(methyl methacrylate) microchips for electrophoretic separation of biomolecules. Journal of pharmaceutical and biomedical analysis 2010, 53(5): 1272-1277

\section{ISSUE DATE:}

2010-12-15

URL:

http://hdl.handle.net/2433/126730

\section{RIGHT:}

(C) 2010 Elsevier B.V.; This is not the published version. Please cite only the published version.; この論文は出版社版でありません。引用の際に は出版社版をご確認ご利用ください。 


\section{One-step Preparation of Amino-PEG modified Poly(methyl methacrylate) Microchips for Electrophoretic Separation of Biomolecules}

Fumihiko Kitagawa*, Kei Kubota, Kenji Sueyoshi, Koji Otsuka

Department of Material Chemistry, Graduate School of Engineering, Kyoto

University, Katsura, Nishikyo-ku, Kyoto 615-8510, Japan

*To whom correspondence should be addressed.

Tel.: +81-75-383-2448; fax: +81-75-383-2450.

E-mail address: fkitagawa@anchem.mc.kyoto-u.ac.jp (F. Kitagawa).

$U R L:$ http://anchem.mc.kyoto-u.ac.jp/

Keywords: Microchip electrophoresis; Protein analysis; Chiral analysis; Poly(methyl methacrylate); PEG 


\begin{abstract}
A simple method for a chemical surface modification of poly(methyl methacrylate) (PMMA) microchips with amino-poly(ethyleneglycol) $\left(\mathrm{PEG}-\mathrm{NH}_{2}\right)$ by nucleophilic addition-elimination reaction was developed to improve the separation efficiency and analytical reproducibility in a microchip electrophoresis (MCE) analysis of biomolecules such as proteins and enantiomers. In our procedure, the PEG chains were robustly immobilized only by introducing an aqueous solution of $\mathrm{PEG}-\mathrm{NH}_{2}$ into the PMMA microchannel. The electroosmotic mobilities on the modified chips remained almost constant during 35 days with 37 runs without any recoating. The PEG- $\mathrm{NH}_{2}$ modified chip provided a fast, reproducible, efficient MCE separation of proteins with a wide variety of isoelectric points within 15 s. Furthermore, the application of the modified chip to affinity electrophoresis using bovine serum albumin gave a good chiral separation of amino acids.
\end{abstract}




\section{Introduction}

The integration of various chemical/analytical operations on a microchip, which is called micro-total analysis systems ( $\mu$-TAS), allows the minimal sample consumption, fast sample pretreatment, chemical reaction, analysis, and detection. In $\mu$-TAS, polymeric substrates have attracted much attention due to low cost, easy replication, and disposability. Among several operations in $\mu$-TAS, microchip electrophoresis (MCE) is one of the most important separation techniques, and thus the application of polymer channel chips to MCE has been studied during past 15 years [1-9].

In the MCE analysis of proteins, sample adsorption onto the surface of a separation microchannel should reduce the separation efficiency and the analytical reproducibility $[10,11]$. It has been well-known that dynamic coating of several polymers is one of the useful approaches for suppressing the protein adsorption [12-15]. However, desorption of the coated polymers from the surface of the microchannel is sometimes problematic, e.g., in case of the MCE separation combined with mass spectrometric detection. In the covalent bonding methods, on the other hand, stable coating can be obtained but troublesome and time-consuming modification processes are often required [13-22]. Glass/quartz microchips can be chemically modified on the basis of silane chemistry, while for polymeric channel chips chemical modification techniques have not been well established. Thus, a stable modification of polymer chips with a simple procedure is still desired in MCE.

In our previous study, a poly(methyl methacrylate) (PMMA) chip was modified with poly(ethyleneimine) (PEI) by nucleophilic addition-elimination reaction [23-25] for the MCE analysis of cationic proteins [26]. In the nucleophilic addition-elimination, esters in PMMA undergo at their acyl carbon atoms when treated with primary or secondary amines in the presence of electron donators in a basic aqueous solution. The binding of amine to PMMA is most likely an SN2 reaction in which the primary amino groups in coating polymer are involved in a nucleophilic attack on electron-poor carbon on the surface esters of the PMMA, resulting in elimination of a methanol from the ester. In this modification, therefore, an aqueous solution of coating polymer is only introduced into non-activated PMMA microchannel. Although the surface adsorption of cationic proteins could be well suppressed on the PEI modified PMMA chip due to the electrostatic repulsion force, the modified chip could not be applied to the MCE analysis of anionic proteins. In this study, to overcome this limitation, we investigated the possibility of the one-step and covalent immobilization of terminal amino-poly(ethyleneglycol) $\left(\mathrm{PEG}-\mathrm{NH}_{2}\right)$ onto the inner surface of PMMA microchannel. PEG is well-known to be effective for suppressing 
the surface adsorption of proteins due to steric repulsive force of the PEG chains [27-29]. Hence, PEG is often employed for dynamic coating of capillary/microchannel. In our procedure, the reaction between acylcarbon of PMMA and primary amino group in $\mathrm{PEG}-\mathrm{NH}_{2}$ dissolved in a basic aqueous solution is expected to proceed as shown in Fig. 1. Effects of the modification of PEG- $\mathrm{NH}_{2}$ onto the PMMA channel surface on the adsorption and the separation performance of proteins were studied. The application of the $\mathrm{PEG}-\mathrm{NH}_{2}$ modified PMMA chip to the affinity MCE (AMCE) analysis of tryptophan enantiomers was also investigated.

\section{Experimental}

\subsection{Chemicals}

Terminal amino-poly(ethyleneglycol) $\left(\mathrm{PEG}-\mathrm{NH}_{2}, M_{\mathrm{W}}=30000\right)$ was obtained from NOF corporation (Tokyo, Japan), rhodamine B isothiocyanate (RBITC), fluorescein isothiocyanate (FITC), bovine serum alubumin (BSA) and myoglobin (MYO) were from SIGMA-ALDRICH (Tokyo, Japan), polyethylene glycol (PEG, $M_{\mathrm{W}}=25000$ ), $N, N$ '-dimethylformamide (DMF) and DL-tryptophan (Trp) from Nacalai Tesque (Kyoto, Japan), sulforhodamine B (SRB) from Tokyo Chemical Industry (Tokyo, Japan), and ribonuclease A (RIB) from Wako (Osaka, Japan). All reagents were of analytical or HPLC grade. Background solutions (BGSs) used in the MCE analysis of proteins and Trp enantiomers were $10 \mathrm{mM}$ borate buffer $(\mathrm{pH} 9.0-10.0)$ and $0.5 \mathrm{mg} / \mathrm{mL}$ BSA in 20 $\mathrm{mM}$ phosphate buffer $(\mathrm{pH}$ 7.2), respectively. All solutions were prepared with deionized water purified by using a Direct-Q System (Nihon Millipore, Japan), and filtered through a $0.45 \mu \mathrm{m}$ pore membrane filter prior to use.

Proteins were labeled with RBITC for laser-induced fluorescence (LIF) detection. An RBITC solution dissolved in DMF was added to a protein solution in $50 \mathrm{mM}$ borate buffer ( $\mathrm{pH} 8.5)$ at a 10:1 RBITC/protein molar ratio. The derivatization was allowed to proceed in the dark at room temperature for $1 \mathrm{~h}$. The reaction mixture was dialyzed to remove unreacted fluorescent dyes by using a cellulose membrane (Slide-A-Lyser Dialysis Cassettes, MWCO 3500, Pierce Biotechnology, Rockford, IL) for $12 \mathrm{~h}$ with 10 $\mathrm{mM}$ borate buffer ( $\mathrm{pH} 9.0-10.0$ ) as a dialysis buffer. Prior to the MCE separation, RBITC labeled proteins were diluted to be $100 \mu \mathrm{g} / \mathrm{mL}$ with an appropriate amount of the BGS. Fluorescence labeling of Trp with FITC was also carried out with the same procedure.

\subsection{Microchip}


A PMMA microchip was kindly supplied from Hitachi Chemical (Tokyo, Japan). The substrate was $85 \times 50 \times 1 \mathrm{~mm}$. The microchip has a simple cross-type channel (100 $\mu \mathrm{m}$ width $\times 30 \mu \mathrm{m}$ depth) with a total separation channel length of $38 \mathrm{~mm}$. Immobilization of PEG- $\mathrm{NH}_{2}$ onto the PMMA channel was carried out using the same procedure in the previous report [26]. Briefly, a solution of $10 \%(\mathrm{w} / \mathrm{w}) \mathrm{PEG}-\mathrm{NH}_{2}$ in $100 \mathrm{mM}$ borate buffer ( $\mathrm{pH}$ 12.5) was pumped through the microchannel at a flow rate of $1.7 \mu \mathrm{L} / \mathrm{min}$ for $6 \mathrm{~h}$ using a syringe pump (KDS100, kd Scientific, Holliston, MA), followed by rinsing with deionized water for $20 \mathrm{~min}$. The modified PMMA microchip was then dried at $30{ }^{\circ} \mathrm{C}$ overnight. The channel was conditioned with the BGS for 10 min prior to the MCE measurement.

\subsection{Apparatus}

MCE analysis of fluorescent samples was performed using a home-made LIF detection scheme as reported previously [26]. A 532-nm laser beam (10 mW diode-pumped solid-state laser, 58GCS411, Melles Griot, Tokyo, Japan) or 488-nm laser beam $(20 \mathrm{~mW}$ solid-state laser, 85BCD020, Melles Griot) for excitation was introduced to an inverted optical microscope (IX71, Olympus, Tokyo, Japan) and, irradiated to the microchannel (spot size for excitation, $c a .10 \mu \mathrm{m}$ ) through an objective lens $(\times 20, \mathrm{NA}=0.40$, LCPlanFL-20X, Olympus $)$. Fluorescence from analytes collected by the same objective lens was passed through a dichroic filter (U-MWIG2 and U-MNIBA2 (Olympus) for 532- and 488-nm excitation, respectively) and led to a multichannel photodetector (PMA-11, Hamamatsu Photonics, Hamamatsu, Japan). For the fluorescence imaging measurement, an 100-W mercury lamp (HBO103W/2, OSRAM, Augsburg, Germany) and a CCD camera (1K-TU53H, Toshiba, Tokyo, Japan) were used as a light source and a detector, respectively. The microchip was placed on the 3D-stage of the microscope and the MCE separation was performed with a 5 channel-type high voltage power supply (Shimadzu, Kyoto, Japan).

\subsection{Procedure}

The channels were filled with the BGS. Prior to separation, the sample solution (7 $\mu \mathrm{L}$ ) was introduced into the sample reservoir and a platinum electrode was inserted into each reservoir to provide the electrical contact. To introduce the sample solution into the separation channel, the pinched injection technique [30] was employed. Voltage programs for the injection on bare and $\mathrm{PEG}-\mathrm{NH}_{2}$ modified chips are summarized in Table 1. Except for the MCE analysis of proteins on the bare PMMA chip, the sample 
introduction was carried out mainly by means of the electrophoretic migration of the anionic analytes with the reversed polarity. Since the electroosmotic mobility on the bare PMMA chip was larger than the electrophoretic mobility of the sample proteins at $\mathrm{pH}$ 10.0, the sample injection was performed with the EOF under the normal polarity condition. These voltage programs were also employed for the EOF rate measurements.

\section{Results and discussion}

\subsection{Characterization of $\mathrm{PEG}-\mathrm{NH}_{2}$ Modified Microchip}

In the modification of PEG- $\mathrm{NH}_{2}$ onto the inner surface of the PMMA channel, the degree of the modification was evaluated from the electroosmotic mobility $\left(\mu_{\mathrm{eo}}\right)$. Since the EOF was suppressed in the PEG- $\mathrm{NH}_{2}$ coated channel, neutral EOF marker or current monitoring method [31] could not be employed to determine the EOF rate in MCE. To evaluate the EOF velocity, hence, the fluorescent SRB was analyzed to calculate the apparent electrophoretic mobility $\left(\mu_{\text {app }}\right)$. By subtracting the electrophoretic mobility of SRB obtained in the CE experiments $\left(1.3 \times 10^{-4} \mathrm{~cm}^{2} \mathrm{~V}^{-1} \mathrm{~s}\right.$ in $10 \mathrm{mM}$ phosphate buffer ( $\mathrm{pH} 7.0)$ ), the EOF velocity in the channel was determined. On the bare PMMA chip, an anodic EOF was observed with $\mu_{\mathrm{eo}}$ of $+1.8 \times 10^{-4} \mathrm{~cm}^{2} \mathrm{~V}^{-1} \mathrm{~s}$ at $\mathrm{pH} 7.0[32,33]$. By immobilizing $\mathrm{PEG}-\mathrm{NH}_{2}$ on the PMMA channel, $\mu_{\mathrm{eo}}$ was apparently decreased as shown in Table 2. To optimize the immobilization condition of PEG- $\mathrm{NH}_{2}$, the reaction time and temperature were varied. Both $\mu_{\mathrm{eo}}$ and its relative standard deviation (RSD) were decreased with increasing the modification time from 2 $\mathrm{h}$ to $12 \mathrm{~h}$ at higher temperature, indicating the increase in the immobilization amount of $\mathrm{PEG}-\mathrm{NH}_{2}$. In this study, the reaction time and temperature were set at $6 \mathrm{~h}$ and $70{ }^{\circ} \mathrm{C}$, respectively. Comparing the immobilization of PEI onto the PMMA channel in our previous study $\left(2 \mathrm{~h}, 25^{\circ} \mathrm{C}\right)[26]$, the long reaction time and high temperature was required in modifying PEG- $\mathrm{NH}_{2}$. This is due to small amount of amino groups in PEG- $\mathrm{NH}_{2}$ (only one amino group bounds to PEG with $M \mathrm{w}$ 30000) relative to PEI. The effect of the molecular weight of $\mathrm{PEG}-\mathrm{NH}_{2}$ on the modification was also investigated. As a result, the PMMA chip modified with $\mathrm{PEG}-\mathrm{NH}_{2}$ of smaller molecular weight $(M \mathrm{w}=1000,20000)$ showed lower ability for suppressing the adsorption of proteins and lower stability of the coating layer than $M \mathrm{w} 30000$. Thus, PEG- $\mathrm{NH}_{2}$ with $\mathrm{Mw} 30000$ was employed in the remaining study. Such high molecular weight PEG would be effective to avoid the adsorption of rather high-molecular weight proteins [27-29].

To investigate the durability of the PEG- $\mathrm{NH}_{2}$ coating onto the PMMA surface, 6 7 
replicate measurements were carried out every seven days. As shown in Fig. 2, the $\mu_{\text {app }}$ of SRB was almost constant during 37 runs within 35 days. This indicated that $\mu_{\mathrm{eo}}$ on the PEG- $\mathrm{NH}_{2}$ coated channel remained almost constant during approximately 1 month. The day-to-day reproducibility of $\mu_{\text {eo }}$ was acceptable with the RSD of $9.6 \%$ ( $n$ $=4$ within first 21 days) under the dry storage condition.

To compare the physical coating, the modification polymer was replaced from PEG-NH $\mathrm{NH}_{2}$ to normal PEG ( $\left.\mathrm{ww} 25000\right)$. The PMMA chip modified with PEG at the same condition (10\% PEG, $\left.\mathrm{pH} 12.5,6 \mathrm{~h}, 70{ }^{\circ} \mathrm{C}\right)$ gave a sharp peak of BSA at first run. After only 5 consecutive runs, however, the peak width became broader and the detection time was increased from $30 \mathrm{~s}$ to $85 \mathrm{~s}$, indicating the desorption of PEG from the PMMA surface. Hence, the longer stability of the PEG- $\mathrm{NH}_{2}$ coated microchip demonstrated that the loss of $\mathrm{PEG}-\mathrm{NH}_{2}$ was successfully suppressed by the immobilization via the covalent bonding between amino groups in $\mathrm{PEG}-\mathrm{NH}_{2}$ and acyl carbon on the PMMA surface. Since the coating was carried out with alkaline solutions, furthermore, there is a possibility of slight hydrolysis of PMMA, resulting in a negatively charged surface. The electrostatic interaction between the positively charged amino groups in PEG- $\mathrm{NH}_{2}$ and the negatively charged PMMA surface should stabilize the PEG- $\mathrm{NH}_{2}$ coating layer. Therefore, the stable PEG-NH${ }_{2}$ coating on the PMMA surface might be obtained by the cooperative immobilization based on the covalent bonding and the electrostatic interaction.

\subsection{MCE Analysis of Proteins on PEG-NH $\mathrm{H}_{2}$ Modified PMMA Chips}

To evaluate the analytical performance of the PEG- $\mathrm{NH}_{2}$ modified chip, the MCE analysis of BSA was carried out. As shown in Fig. 3, a broad peak was obtained on the bare PMMA microchip, whereas in the PEG- $\mathrm{NH}_{2}$ modified channel a sharper peak was observed at $11.6 \mathrm{~s}$. The efficiency was increased from 150 to 1450 by immobilizing the $\mathrm{PEG}-\mathrm{NH}_{2}$ onto the PMMA channel surface. On the PEG- $\mathrm{NH}_{2}$ modified chip, furthermore, the RSD of the detection time was better $(1.8 \%)$ than the bare PMMA channel (9.4\%). Fig. 4 shows the fluorescence images of the bare and PEG- $\mathrm{NH}_{2}$ modified PMMA chips after 10 consecutive runs of fluorescently labeled BSA. On the bare PMMA chip, a strong fluorescence from the adsorbed BSA was observed from the entire channel surface, while on the PEG- $\mathrm{NH}_{2}$ modified channel the surface adsorption of BSA was apparently reduced. Thus, the sharp peak observed in Fig. $3 \mathrm{~b}$ was due to the suppression of the surface adsorption of the analytes by the $\mathrm{PEG}-\mathrm{NH}_{2}$ coating.

In the MCE separation of proteins, BSA (pI 4.0), MYO (pI 7.2) and RIB (pI 9.2) 
were used as the test mixture. On the bare PMMA chip, the separation of RIB and MYO was insufficient as shown in Fig. 5a. On the other hand, a successful separation of three proteins was achieved on the $\mathrm{PEG}-\mathrm{NH}_{2}$ modified chip within $15 \mathrm{~s}$ only utilizing a separation length of $5 \mathrm{~mm}$ (Fig. 5b). Comparing the PEG- $\mathrm{NH}_{2}$ modified chip with the bare PMMA, the migration order of the proteins was reversed. This was due to the reversal polarity of the separation voltage as mentioned in the Experimental section. Since $\mu_{\mathrm{eo}}$ on the bare chip was larger than the electrophoretic mobilities of the negatively-charged proteins, the analytes migrated toward the cathode. On the PEG- $\mathrm{NH}_{2}$ modified chip, on the other hand, the EOF was well suppressed and the polarity of the separation voltage was negative, so that the anionic analytes moved toward the anode. As summarized in Table 3, the efficiencies were improved from $110-190$ to $550-3400$ by the PEG- $\mathrm{NH}_{2}$ coating. In addition, the RSDs of the detection time were $4-18 \%$ on the bare PMMA chip, whereas on the PEG- $\mathrm{NH}_{2}$ modified chip the RSD values were improved to less than 4\%. These results demonstrated that the PEG- $\mathrm{NH}_{2}$ immobilized on the PMMA surface could avoid the irreversible adsorption of proteins, which provided a high performance analysis medium for proteins with a wide variety of isoelectric points.

\subsection{Application to affinity MCE analysis of enantiomers}

In affinity electrophoresis, a BGS containing affinity ligands is employed for the separation of closely-resembled biogenic compounds. It has been well-known that several proteins such as BSA, avidin, ovomucoid and $\alpha_{1}$-acid glycoprotein, show chiral recognition ability for racemic amino acids and drug components. Hence, affinity electrophoresis is one of the most effective separation modes for the chiral analysis in CE [34]. On the other hand, only a few reports on the application of affinity electrophoresis using chiral selective proteins as additives in the BGS to MCE has appeared [35] since the adsorption of affinity ligands onto the channel surface makes the electrokinetic sample injection difficult, resulting in poor reproducibility [36]. To overcome this problem, the $\mathrm{PEG}-\mathrm{NH}_{2}$ modified PMMA chips were employed to the affinity MCE (AMCE) analysis of Trp enantiomers by using BSA as the affinity ligand.

On the basis of the results of affinity CE experiments with BSA by Liu et al. [37], $0.5 \mathrm{mg} / \mathrm{mL}$ BSA in $20 \mathrm{mM}$ phosphate buffer (pH 7.2) was selected as the BGS in the present AMCE analysis. Even on the bare PMMA chips, Trp enantiomers could be separated by AMCE at the first run as shown in Fig. 6a. At the second run, however, a single peak was obtained. Such low repeatabilities on the bare PMMA chips would be caused by poor sample injection. In each run, the surface condition of the bare PMMA 
might be changed by unstable surface adsorption of BSA, resulting in low repeatability of injected sample amount. On the other hand, the chiral separations of Trp were attained within $40 \mathrm{~s}$ on the PEG- $\mathrm{NH}_{2}$ modified PMMA chip during 10 consecutive runs. As shown in Fig. 6b, closely-resembled electropherograms were obtained at both the first and fifth runs. The repeatability of the detection time was better with the RSD of $1.8 \%(n=5)$ on the modified chip, while on the bare PMMA chip the RSD was $6.9 \%$. These results showed that, therefore, the $\mathrm{PEG}-\mathrm{NH}_{2}$ modification onto the PMMA channel was effective for not only zone electrophoresis separation of proteins but chiral AMCE analysis using proteins as additives to the BGS.

\section{Conclusions}

To reduce irreversible adsorption of proteins, one-step immobilization of PEG- $\mathrm{NH}_{2}$ onto the surface of the PMMA microchips was developed on the basis of nucleophilic addition-elimination reaction. By using the modified microchips, efficient and reproducible MCE analyses of proteins and racemic amino acids were attained. The application of both PEG-NH $\mathrm{NH}_{2}$ and PEI modified PMMA chips to MCE should be useful for the separation of anionic, cationic and neutral proteins and peptides, which will be valuable to high-throughput proteomic analyses.

\section{Acknowledgments}

The authors thank Mr. Kazuyoshi Kurihara (Hitachi Chemical Co., Ltd.) for supplying the PMMA microchip. F.K. is grateful to the Grant-in-Aid for Young Scientists (B) (No. 20750060) from the Ministry of Education, Culture, Sports, Science and Technology of Japan (MEXT). This research was partly supported by Grant-in-Aid for the Global COE Program, "International Center for Integrated Research and Advanced Education in Materials Science," from MEXT.

\section{References}

[1] C.S. Effenhauser, G.J.M. Bruin, A. Paulus, M. Ehrat, Integrated capillary electrophoresis on flexible silicone microdevices: analysis of DNA restriction fragments and detection of single DNA molecules on microchips, Anal. Chem. 69 (1997) 3451-3457.

[2] D.C. Duffy, J.C. McDonald, O.J.A. Schueller, G.M. Whitesides, Rapid prototyping of microfluidic systems in poly(dimethylsiloxane), Anal. Chem. 70 (1998) 4974-4984. 
[3] Z. Meng, S. Qi, S.A. Soper, P.A. Limbach, Interfacing a polymer-based micromachined device to a nonoelectrospray ionization Fourier transform ion cyclotron resonance mass spectrometer, Anal. Chem. 73 (2001) 1286-1291.

[4] Y.H. Chen, S.H. Chen, Analysis of DNA fragments by microchip electrophoresis fabricated on poly(methyl methacrylate) substrates using a wire-imprinting method, Electrophoresis 21 (2000) 165-170.

[5] S.L.R. Barker, M.J. Tarlov, H. Canavan, J.J. Hickman, L.E. Locascio, Plastic microfluidic devices modified with polyelectrolyte multilayers, Anal. Chem. 72 (2000) 4899-4903.

[6] Y. Liu, D. Ganser, A. Schneider, R. Liu, P. Grodzinski, N. Kroutchinina, Microfabricated polycarbonate CE devices for DNA analysis, Anal. Chem. 73 (2001) 4196-4201.

[7] F. Bianchi, Y. Chevolot, H.J. Mathieu, H.H. Girault, Photomodification of polymer microchannels induced by static and dynamic excimer ablation: effect on the electroosmotic flow, Anal. Chem. 73 (2001), 3845-3853.

[8] J. Kameoka, H.G. Craighead, H. Zhang, J. Henion,, A polymeric microfluidic chip for CE/MS determination of small molecules, Anal. Chem. 73 (2001) 1935-1941.

[9] H. Shinohara, T. Suzuki, F. Kitagawa, J. Mizuno, K. Otsuka, S. Shoji, Polymer microchip integrated with nano electrospray tip for electrophoresis-mass spectrometry, Sens. Actuators B 132 (2008) 368-373.

[10] Y. Peng, A. Pallandre, N.T. Tran, M. Taverna, Recent innovations in protein separation on microchips by electrophoretic methods, Electrophoresis 29 (2008) $157-178$.

[11] D. Wu, J. Qin, B. Lin, Electrophoretic separations on microfluidic chips, J. Chromatogr. A 1184 (2008) 542-559.

[12] M.M. Hsieh, T.C. Chiu, W.L. Tseng, H.T. Chang, Analysis of nucleic acids and proteins by capillary electrophoresis and microchip capillary electrophoresis using polymers as additives of the background electrolytes, Curr. Anal. Chem. 2 (2006) $17-33$.

[13] E.A.S. Doherty, R.J. Meagher, M.N. Albarghouthi, A.E. Barron, Microchannel wall coatings for protein separations by capillary and chip electrophoresis, Electrophoresis 24 (2003) 34-54.

[14] D. Belder, M. Ludwig, Surface modification in microchip electrophoresis, Electrophoresis 24 (2003) 3595-3606.

[15] V. Dolnik, Wall coating for capillary electrophoresis on microchips, Electrophoresis 25 (2004) 3589-3601. 
[16] A. Muck, A. Svatos, Chemical modification of polymeric microchip devices, Talanta 74 (2007) 333-341.

[17] J. Liu, M.L. Lee, Permanent surface modification of polymeric capillary electrophoresis microchips for protein and peptide analysis, Electrophoresis 27 (2006) 3533-3546.

[18] A.C. Henry, T.J. Tutt, M. Galloway, Y.Y. Davidson, C.S. McWhorter, S.A. Soper, R.L. McCarley, Surface modification of poly(methyl methacrylate) used in the fabrication of microanalytical devices, Anal. Chem. 72 (2000) 5331-5337.

[19] J. Liu, T. Pan, A.T. Woolley, M.L. Lee, Anal. Chem. Surface-modified poly(methyl methacrylate) capillary electrophoresis microchips for protein and peptide analysis, 76 (2004) 6948-6955.

[20] H. Nagata, M. Tabuchi, K. Hirano, Y. Baba, High speed separation of proteins by microchip electrophoresis using a PEG-coated plastic chip with an SDS-linear polyacrylamide solution, Electrophoresis 26 (2005) 2687-2691.

[21] T. Pan, G.S. Fiorini, D.T. Chiu, A.T. Woolley, In-channel atom-transfer radical polymerization of thermoset polyester microfluidic devices for bioanalytical applications, Electrophoresis 28 (2007) 2904-2911.

[22] X. Sun, J. Liu, M.L. Lee, Surface modification of glycidyl-containing poly(methyl methacrylate) microchips using surface-initiated atom-transfer radical polymerization, Anal. Chem. 80 (2008) 856-863.

[23] R.T. Morrison, R.N. Boyd, Organic Chemistry, sixth ed., Prentice-Hall International Inc., New Jersey, 1992, pp. 778.

[24] F. Fixe, M. Dufva, P. Telleman, C.B.V. Christensen, Functionalization of poly(methyl methacrylate) (PMMA) as a substrate for DNA microarrays, Nucleic Acids Res. 32 (2004) e9.

[25] F. Fixe, M. Dufva, P. Tellemanc, C.B.V. Christensen, One-step immobilization of aminated and thiolated DNA onto poly(methylmethacrylate) (PMMA) substrates, Lab Chip 4 (2004) 191-195.

[26] F. Kitagawa, K. Kubota, K. Sueyoshi, K. Otsuka, One-step immobilization of cationic polymer onto a poly(methyl methacrylate) microchip for high performance electrophoretic analysis of proteins, Sci. Technol. Adv. Mater. 7 (2006) 558-565.

[27] S.I. Jeon, J.H. Lee, J.D. Andrade, P.G. de Gennes, Protein-surface interactions in the presence of polyethylene oxide: simplified theory, J. Colloid Interface Sci. 142 (1991) 149-158.

[28] S.I. Jeon, J.H. Lee, J.D. Andrade, P.G. de Gennes, Protein-surface interactions in 
the presence of polyethylene oxide II. Effect of protein size, J. Colloid Interface Sci. 142 (1991) 159-166.

[29] P. Kingshott, H. Thissen, H.J. Griesser, Effects of cloud point grafting, chain length, and density of PEG layers on adsorption of ocular proteins, Biomaterials 23 (2002) 23, 2043-2056.

[30] S.C. Jacobson, R. Hergenroder, A.W. Moore, J.M. Ramsey, Precolumn reactions with electrophoretic analysis integrated on a microchip, Anal. Chem. 66 (1994) 4127-4132.

[31] A. Sze, D. Erickson, L. Ren, D. Li, Zeta-potential measurement using the Smoluchowski equation and the slope of the current-time relationship in electroosmotic flow, J. Colloid Interface Sci. 261 (2003) 402-410.

[32] L.E. Locascio, C.E. Perso, C.S. Lee, Measurement of electroosmotic flow in plastic imprinted microfluid devices and the effect of protein adsorption on flow rate, J. Chromatogr. A 857 (1999) 275-284.

[33] D.L. Pugmire, E.A. Waddell, R. Haasch, M.J. Tarlow, L.E. Locascio, Surface characterization of laser-ablated polymers used for microfluidics, Anal. Chem. 74 (2002) 871-878.

[34] J. Haginaka, Enantiomer separation of drugs by capillary electrophoresis using proteins as chiral selectors, J. Chromatogr. A 875 (2000) 235-254.

[35] X. Weng, H. Bi, B.Liu, J. Kong, On-chip separation based on bovine serum albumin-conjugated carbon nanotubes as stationary phase in a microchannel, Electrophoresis 27 (2006) 3129-3135.

[36] G.E. Barker, P. Russo, R.A. Hartwick, Chiral separation of leucovorin with bovine serum albumin using affinity capillary electrophoresis, Anal. Chem. 64 (1992) 3024-3028.

[37] Z. Liu, H. Zou, J. Y. Ni, Y. Zhang, Open tubular capillary electrochromatography with adsorbed stationary phase, Anal. Chim. Acta 378 (1999) 73-76. 


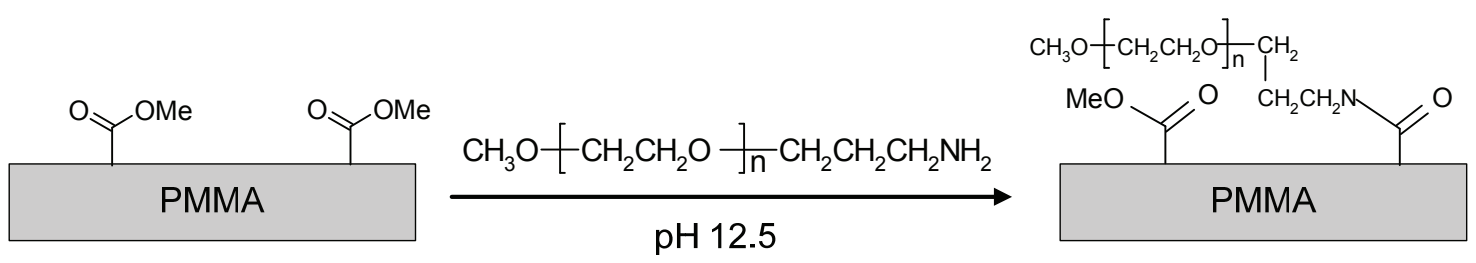

Fig. 1. Covalent immobilization of PEG- $\mathrm{NH}_{2}(n=680, M \mathrm{w}=30000)$ onto the PMMA surface. 


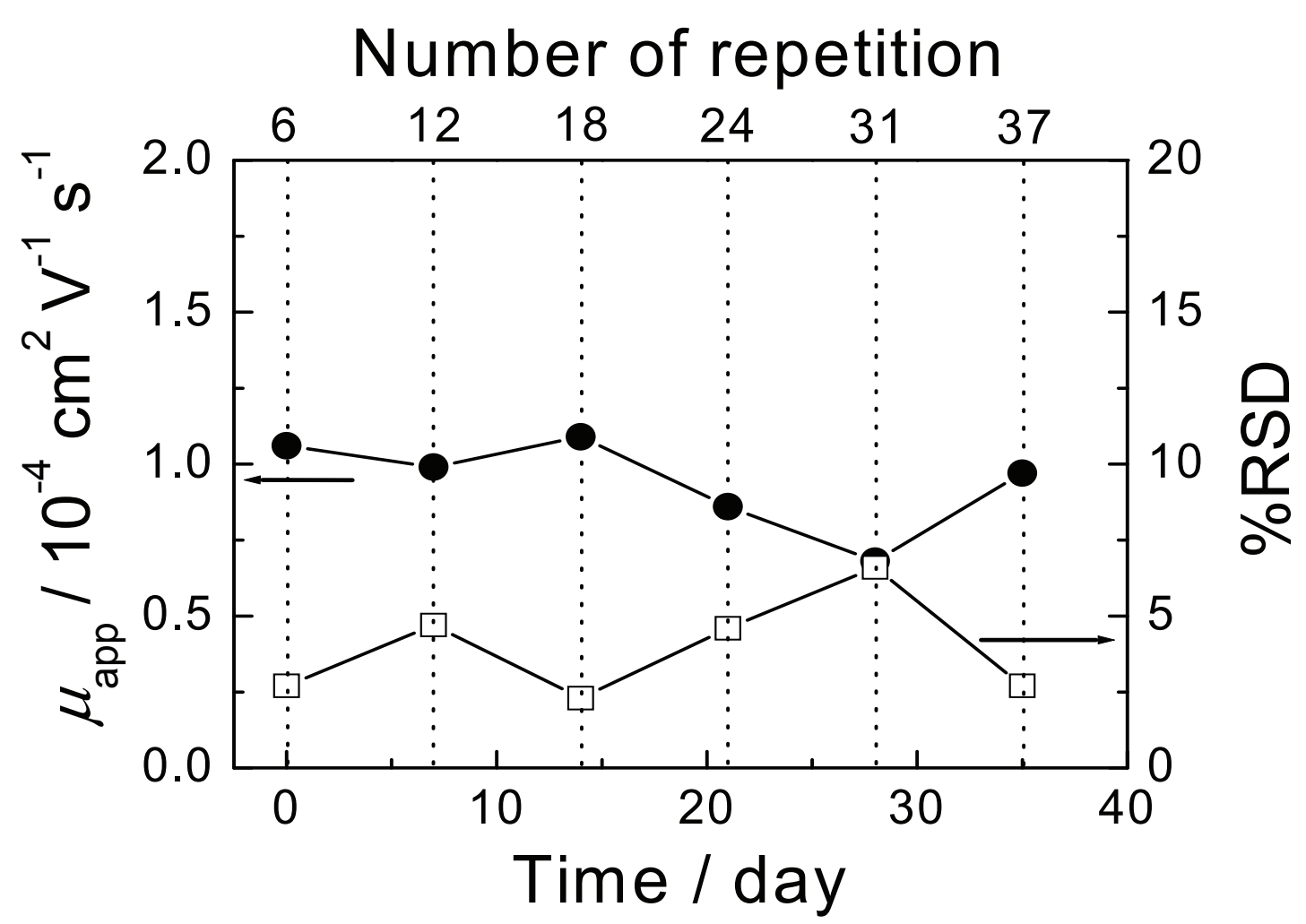

Fig. 2. Long-term stability of the $\mathrm{PEG}-\mathrm{NH}_{2}$ modified PMMA microchip. The $\mu_{\text {app }}$ values were determined from the migration time of SRB in $10 \mathrm{mM}$ phosphate buffer (pH 7.0). \%RSD of $\mu_{\text {app }}$ was calculated from five consecutive runs. 

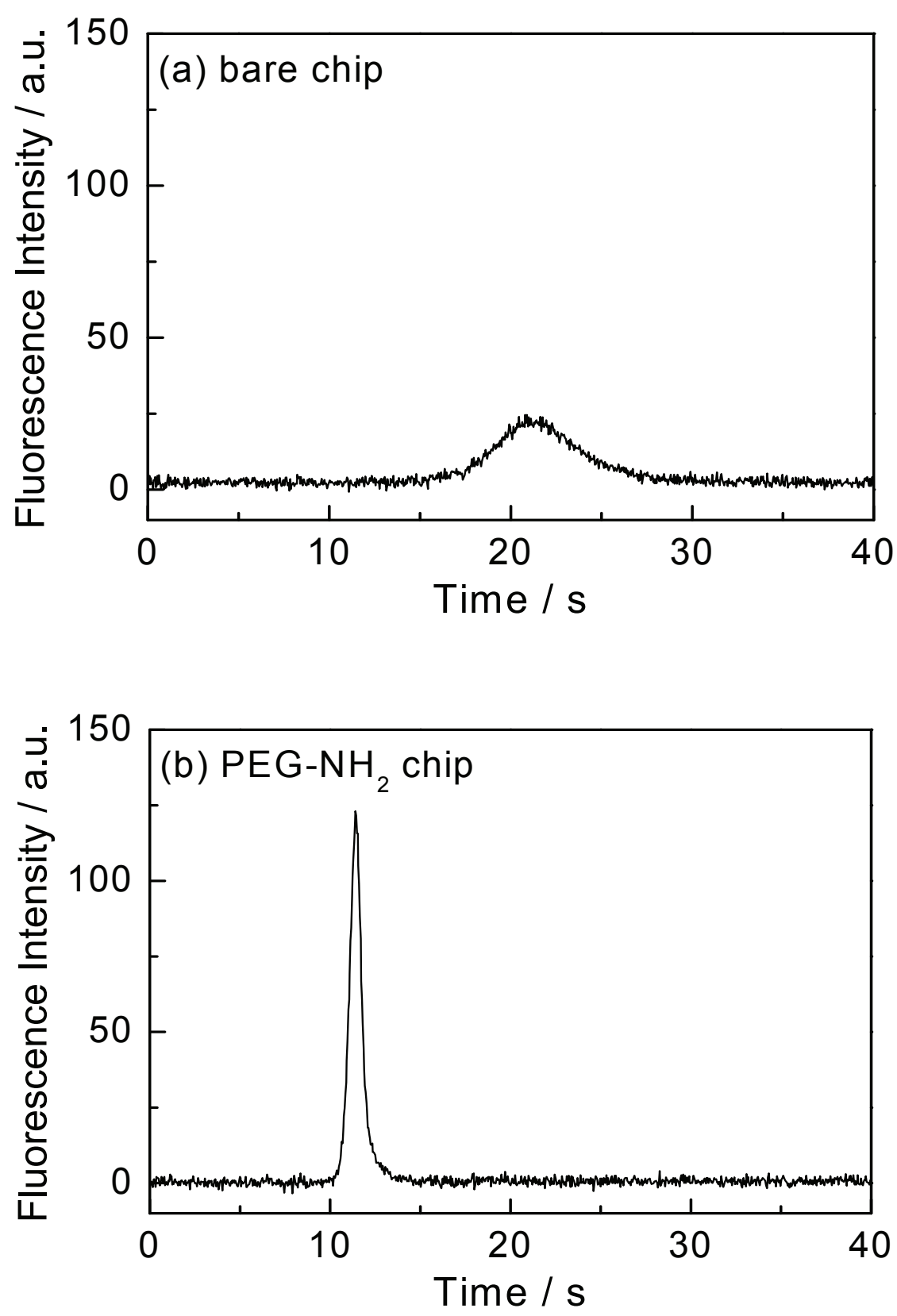

Fig. 3. Electropherograms of 100 ppm BSA on the (a) bare and (b) $\mathrm{PEG}-\mathrm{NH}_{2}$ modified PMMA microchips. Modification condition, $10 \%$ (w/w) $\mathrm{PEG}-\mathrm{NH}_{2}, \mathrm{pH} 12.5,70{ }^{\circ} \mathrm{C}, 6 \mathrm{~h}$; BGS, $10 \mathrm{mM}$ borate buffer ( $\mathrm{pH} 9.0$ ); sample concentration, $100 \mu \mathrm{g} / \mathrm{mL}$; distance of detection point from the injection cross, $5 \mathrm{~mm}$. 

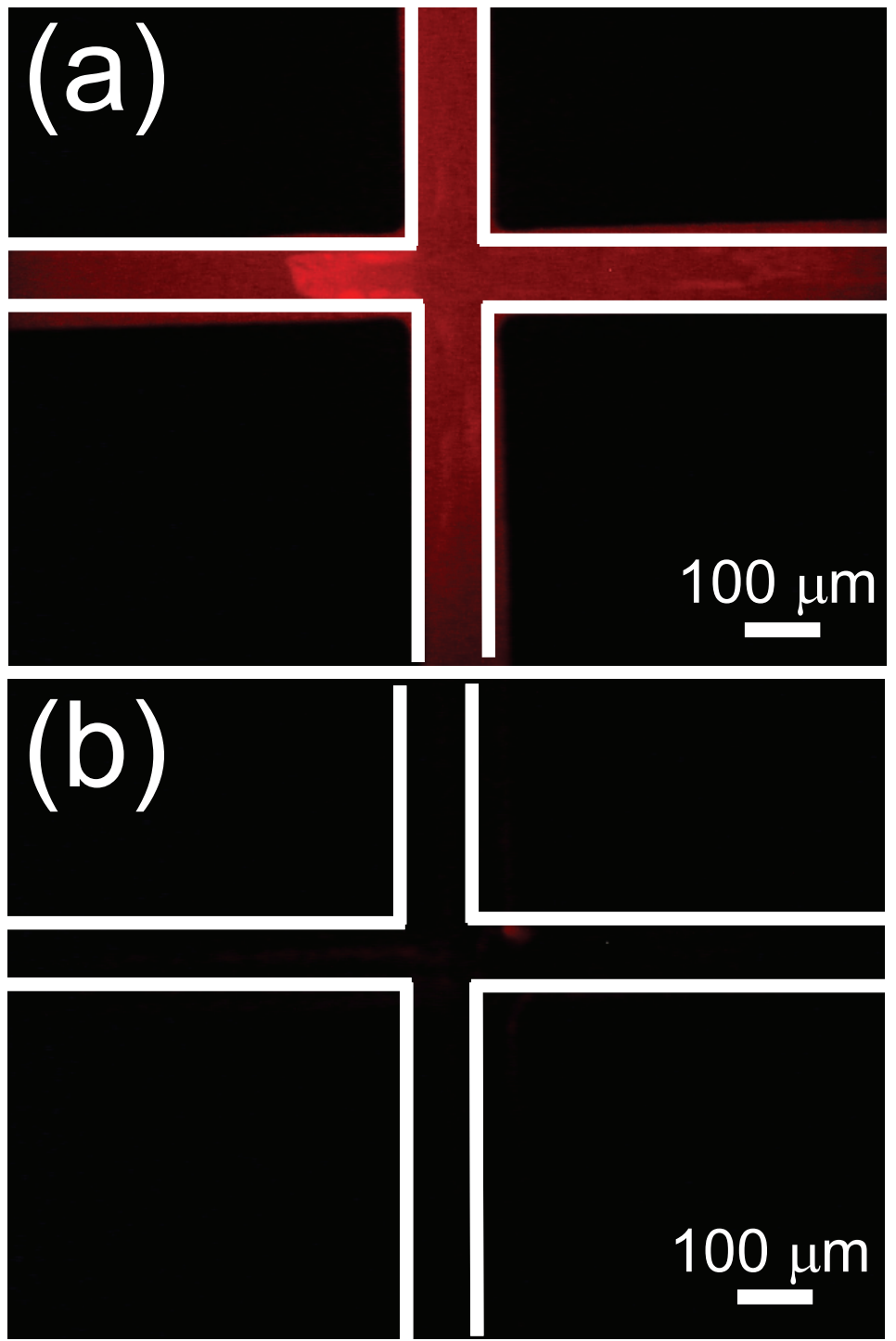

$100 \mu \mathrm{m}$

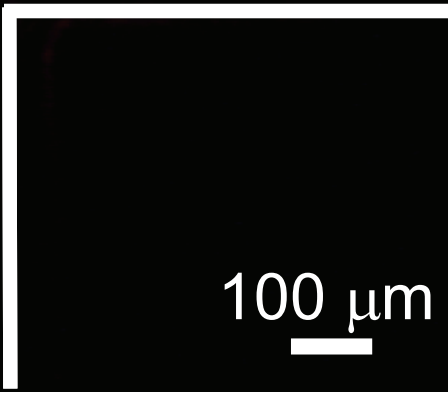

Fig. 4. Fluorescence images of the (a) bare and (b) $\mathrm{PEG}-\mathrm{NH}_{2}$ modified PMMA microchips after 10 consecutive runs of fluorescently labeled BSA. 


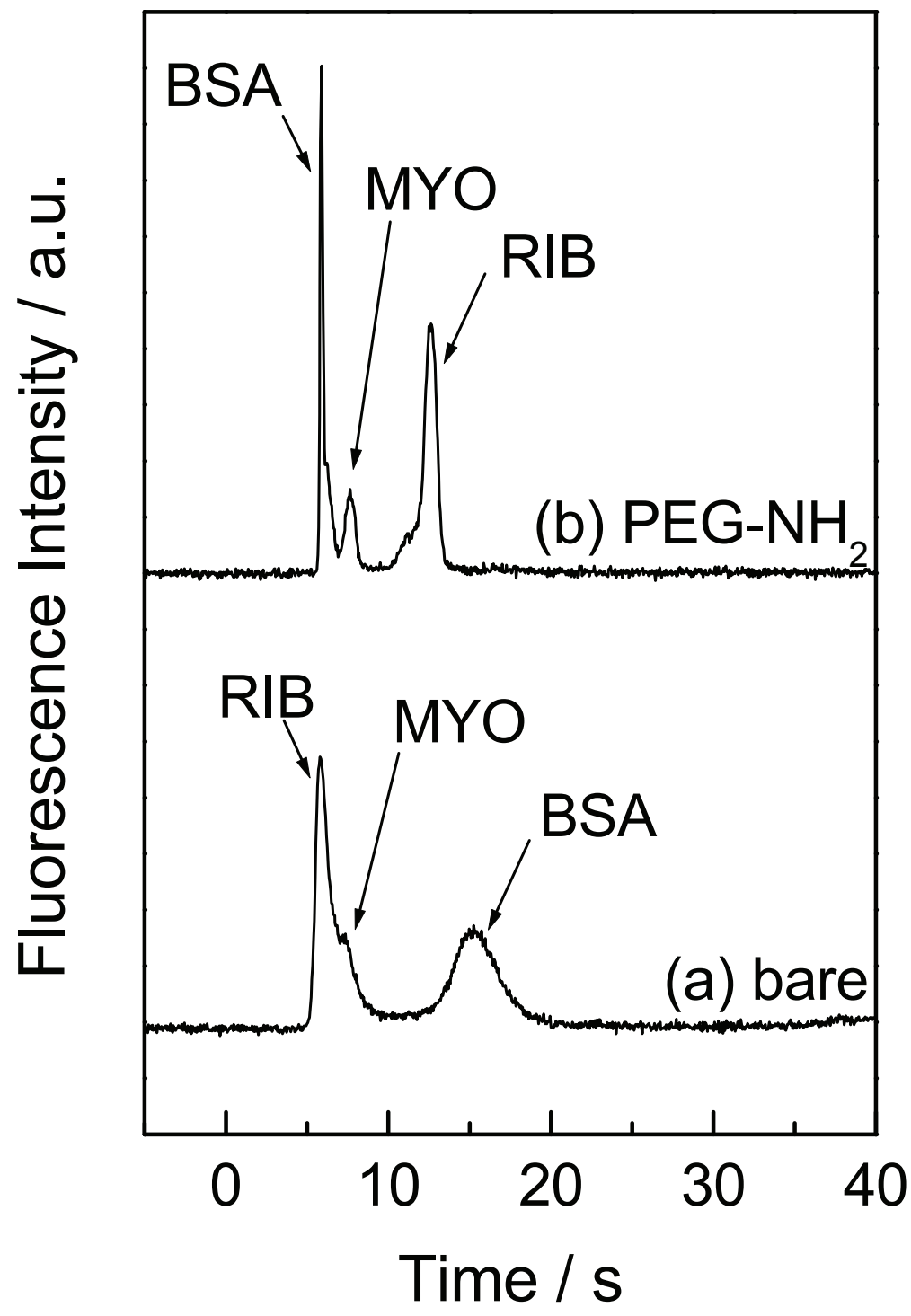

Fig. 5. MCE separation of three proteins on the (a) bare and (b) $\mathrm{PEG}-\mathrm{NH}_{2}$ modified PMMA microchips. BGS, $10 \mathrm{mM}$ borate buffer ( $\mathrm{pH}$ 10.0); sample concentrations, 100 $\mu \mathrm{g} / \mathrm{mL}$ each. Other conditions as in Fig. 2. 

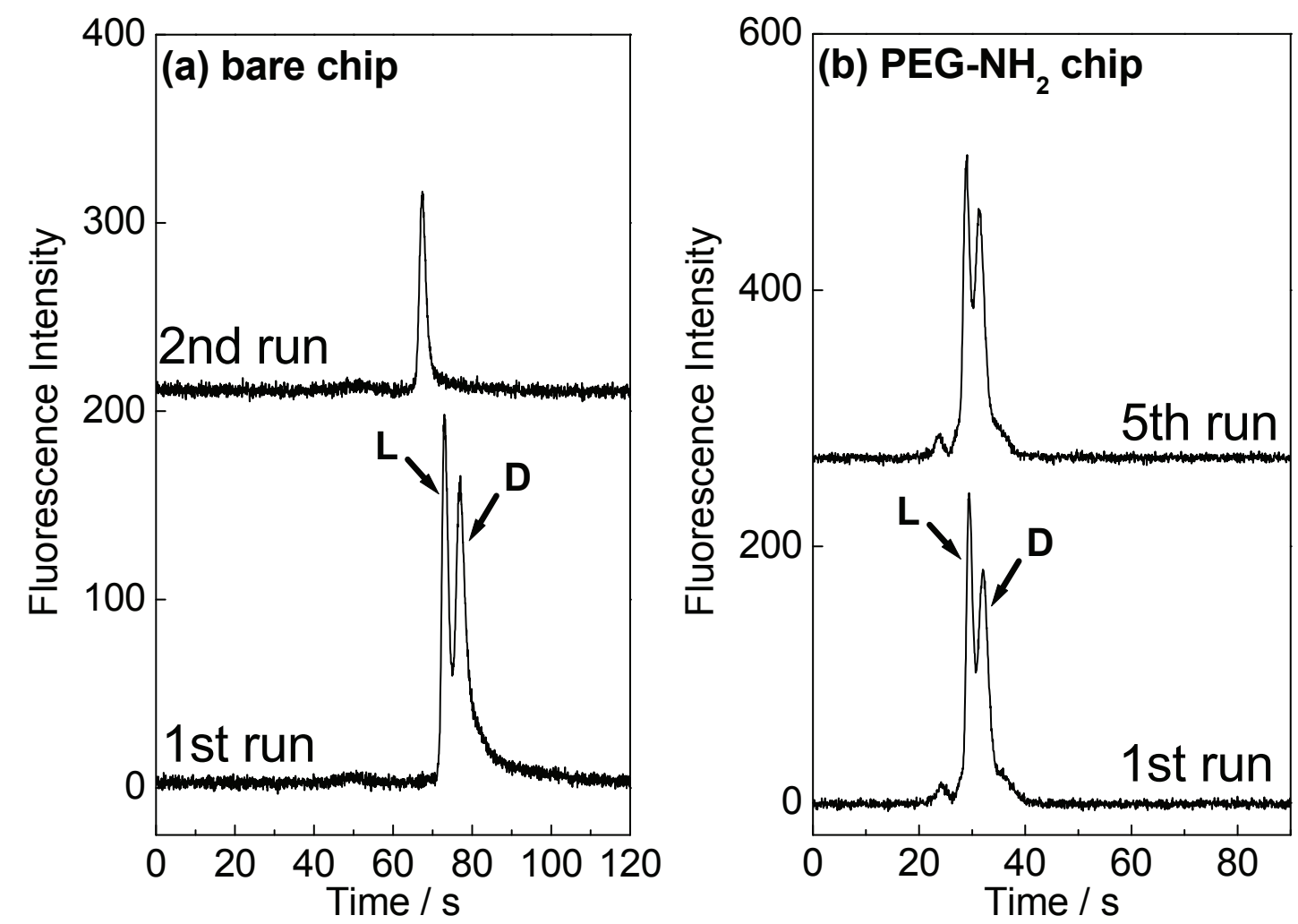

Fig. 6. MCE analysis of FITC labeled-Trp enantiomers on the (a) bare and (b) PEG- $\mathrm{NH}_{2}$ modified PMMA microchips. BGS, $0.5 \mathrm{mg} / \mathrm{mL}$ BSA in $20 \mathrm{mM}$ phosphate buffer ( $\mathrm{pH} 7.2$ ); sample concentration, $1 \mu \mathrm{M}$; distance of detection point from the injection cross, $10 \mathrm{~mm}$. 
Table 1. Voltage programs for the MCE analysis of proteins and enantiomers on the PMMA chips.

\begin{tabular}{|c|c|c|c|c|c|c|c|}
\hline \multirow{2}{*}{ microchip } & \multirow{2}{*}{ step } & \multirow{2}{*}{$\begin{array}{l}\text { time } \\
\text { (s) }\end{array}$} & \multirow{2}{*}{ analytes } & \multicolumn{4}{|c|}{ applied voltage (V) } \\
\hline & & & & S & SW & B & BW \\
\hline \multirow{4}{*}{$\begin{array}{c}\text { PEG-NH} \\
\text { modified } \\
\text { PMMA chip }\end{array}$} & \multirow{2}{*}{ loading } & \multirow{2}{*}{90} & proteins & 0 & 750 & 0 & 0 \\
\hline & & & enantiomers & 0 & 650 & 0 & 0 \\
\hline & \multirow{2}{*}{$\begin{array}{l}\text { injection / } \\
\text { separation }\end{array}$} & \multirow{2}{*}{120} & proteins & 750 & 750 & 0 & 1800 \\
\hline & & & enantiomers & 1050 & 1050 & 0 & 1800 \\
\hline \multirow{4}{*}{$\begin{array}{c}\text { bare PMMA } \\
\text { chip }\end{array}$} & \multirow{2}{*}{ loading } & \multirow{2}{*}{90} & proteins & 650 & 0 & 550 & 500 \\
\hline & & & enantiomers & 0 & 650 & 0 & 0 \\
\hline & \multirow{2}{*}{$\begin{array}{l}\text { injection / } \\
\text { separation }\end{array}$} & \multirow{2}{*}{120} & proteins & 1050 & 1050 & 1800 & 0 \\
\hline & & & enantiomers & 1050 & 1050 & 0 & 1800 \\
\hline
\end{tabular}

Table 2. Effect of the modification condition of $\mathrm{PEG}-\mathrm{NH}_{2}$ on the $\mu_{\mathrm{eo}} \cdot{ }^{a}$

\begin{tabular}{ccccc}
\hline $\begin{array}{c}\text { PEG- } \mathrm{NH}_{2} \\
\text { concentration (\%) }\end{array}$ & $\begin{array}{c}\text { temperature } \\
\left({ }^{\circ} \mathrm{C}\right)\end{array}$ & $\begin{array}{c}\text { modification } \\
\text { time }(\mathrm{h})\end{array}$ & $\begin{array}{c}\mu_{\mathrm{eo}} \\
\left(10^{-4} \mathrm{~cm}^{2} \mathrm{~V}^{-1} \mathrm{~s}^{-1}\right)\end{array}$ & \%RSD of $\mu_{\mathrm{eo}}$ \\
\hline 0 & - & - & $\sim 1.3^{b}$ & - \\
10 & 25 & 2 & $\sim 1.3^{b}$ & - \\
10 & 70 & 2 & $\sim 1.3^{b}$ & - \\
10 & 70 & 4 & 0.48 & 12.4 \\
10 & 25 & 6 & 0.46 & 4.3 \\
10 & 70 & 6 & 0.13 & 2.7 \\
10 & 70 & 12 & 0.12 & 1.5 \\
\hline
\end{tabular}

${ }^{a}$ BGS, $10 \mathrm{mM}$ phosphate buffer (pH 7.0).

${ }^{b}$ SRB could not be detected under the applied fields of both +450 and $-450 \mathrm{~V} / \mathrm{cm}$, and this result allowed a rough estimation: $\mu_{\mathrm{app}}(\mathrm{SRB})=\mu_{\mathrm{eo}}$.

Table 3. MCE separation of proteins on the PMMA chips.

\begin{tabular}{|c|c|c|c|c|c|c|c|c|}
\hline & \multicolumn{4}{|c|}{ PEG-NH ${ }_{2}$ modified chip } & \multicolumn{4}{|c|}{ bare PMMA chip } \\
\hline & $t_{\mathrm{R}} / \mathrm{s}$ & $\%$ RSD & $N$ & $R_{\mathrm{S}}$ & $t_{\mathrm{R}} / \mathrm{s}$ & $\%$ RSD & $N$ & $R_{\mathrm{S}}$ \\
\hline BSA & 6.4 & 3.1 & 3400 & & 18.3 & 18.0 & 110 & 214 \\
\hline MYO & 8.3 & 3.1 & 550 & 334 & 7.8 & 6.1 & - & \\
\hline RIB & 14.0 & 4.0 & 830 & & 5.8 & 3.8 & 190 & \\
\hline
\end{tabular}

